\title{
PENGETAHUAN PETERNAK TENTANG GOOD FARMING PRACTICE (GFP) SAPI POTONG DI KECAMATAN KASREMAN KABUPATEN NGAWI PROVINSI JAWA TIMUR
}

\section{FARMER'S KNOWLEDGE ABOUT GOOD BEEF CATTLE FARMING PRACTICE (GFP) IN KASREMAN DISTRICT, NGAWI DISTRICT EAST JAVA PROVINCE}

\author{
Endri Cahyo Saputro ${ }^{1)}$, Novita Dewi Kristanti ${ }^{2)}$, Luki Amar Hendrawati ${ }^{2)}$ \\ ${ }^{1)}$ Mahasiswa STPP Malang \\ ${ }^{2)}$ Dosen Pembimbing STPP Malang
}

\begin{abstract}
ABSTRAK
Kajian ini bertujuan untuk mendeskripsikan hubungan karakteristik peternak dengan penerapan GFP Sapi Potong di Kecamatan Kasreman. Jumlah sampel 32 orang dengan teknik pengambilan sampel berupa area probability sampling. Analisis data menggunakan Pearson Product Moment dengan tingkat kepercayaan $(\alpha)$ 5\% untuk mengetahui hubungan karakteristik peternak dengan pengetahuan. Hasil kajian menunjukkan bahwa karakteristik peternak berupa umur, pendidikan, jumlah kepemilikan ternak, intensitas penyuluhan dan kekosmopolitan memiliki hubungan yang signifikan dengan penerapan GFP (Sig. $<0,05$ ), dengan hubungan terkuat pada karakteristik intensitas penyuluhan $(\mathrm{r}=0,786)$. Sedangkan karakteristik peternak berupa lama beternak tidak memiliki hubungan yang signifikan dengan penerapan GFP (Sig. ) $0,05)$.
\end{abstract}

Kata kunci : penerapan, Good Farming Practice (GFP), kajian, hubungan

\section{ABSTRACT}

This study aims to describe the characteristic relationship of farmers to the implementation of cattle GFP in Kasreman District. The number of samples are 32 people with sampling technique is area probability sampling. The data analysis using Pearson Product Moment with confidence level $(\alpha) 5 \%$. Characteristics of farmers in the form of age, education, number of livestock ownership, intensity of extension and cosmopolite have a significant relationship with the implementation of GFP, with the strongest relationship on the characteristics of intensity of extension (Sig. <0,05). While the characteristics of farmers in the form of farming experience has no significant relationship with the implementation of GFP (Sig. $>0,05)$.

Keywords : implementation, Good Farming Practice (GFP), study, relationship 


\section{PENDAHULUAN}

\section{Latar Belakang}

Ternak sapi, khususnya sapi potong merupakan salah satu sumber daya penghasil bahan makanan berupa daging yang memiliki nilai ekonomis tinggi. Selain hasil utama berupa daging, ternak sapi potong juga memiliki hasil ikutan lain. Seiring dengan pertambahan dan perbaikan taraf hidup penduduk Indonesia, kebutuhan daging sapi semakin meningkat. Di samping itu, peningkatan kebutuhan daging sapi juga dipengaruhi oleh peningkatan pengetahuan masyarakat akan pentingnya protein hewani. Hal ini menyebabkan bergesernya pola konsumsi penduduk dari semula lebih banyak mengonsumsi karbohidrat namun saat ini beralih mengonsumsi protein hewani (Suryani, 2015:1).

Populasi ternak sapi potong domestik yang belum cukup untuk memenuhi kebutuhan daging sapi domestik memaksa pemerintah untuk mengimpor daging sapi. Perkembangan volume impor daging sapi berfluktuasi dalam 5 tahun terakhir. Puncak volume impor daging sapi terjadi pada tahun 2014 sebanyak 246.609 ton atau setara US\$ 681,229 juta (Suryani, 2015:18). Tahun 2015 pemerintah mengurangi impor daging, tetapi kebijakan tersebut mengakibatkan harga daging melambung tinggi dengan pertumbuhan selama 5 tahun sebesar 9,58\% (Suryani, 2015:17). Pola harga daging sapi selalu naik dan tidak pernah kembali ke nilai awal.

Untuk mengatasi permasalahan ketersediaan dan harga daging sapi tersebut, pemerintah telah merumuskan standar budi daya sapi potong berupa Keputusan Menteri Pertanian Nomor 419/Kpts/OT.210/7/2001 tentang Pedoman Budi Daya Ternak Sapi Potong yang Baik (Good Farming Practice). Pedoman tersebut telah disempurnakan melalui Peraturan Menteri Pertanian Republik Indonesia Nomor 46/Permentan/PK.210/8/2015 tentang Budi Daya Sapi Potong yang Baik.

Kabupaten Ngawi merupakan kabupaten paling barat dari Provinsi Jawa 58 | Jurnal Agriekstensia Vol. 17 No. 1 Juli 2018
Timur yang berbatasan langsung dengan Provinsi Jawa Tengah. Kabupaten Ngawi memiliki luas wilayah $1.295,98 \mathrm{~km}^{2}$ yang terbagi dalam 19 kecamatan dan 217 desa/kelurahan. Populasi ternak sapi potong di Kabupaten Ngawi mencapai 81.373 ekor tersebar merata dalam 19 kecamatan (Ngawi dalam Angka, 2015). Jumlah tersebut mengalami penurunan bila dibanding populasi pada tahun 2013 (90.692 ekor) maupun tahun 2012 (110.850 ekor).

Kecamatan Kasreman sebagai salah satu kecamatan di Kabupaten Ngawi terdiri dari 8 desa dengan total luas wilayah 31,49 $\mathrm{km}^{2}$ dan berjarak $8 \mathrm{~km}$ dari ibukota kabupaten. Populasi ternak sapi potong di Kecamatan Kasreman memiliki kecenderungan menurun. Tahun 2013 populasi sapi potong berjumlah 6.137 ekor. Jumlah tersebut mengalami penurunan pada tahun 2014 menjadi 4.350 ekor dan 4.245 ekor pada tahun 2015 (Kecamatan Kasreman dalam Angka 2016:72).

Untuk meningkatkan populasi ternak sapi potong di Kecamatan Kasreman, diperlukan penerapan Good Farming Practice (GFP) Sapi Potong. Penerapan Good Farming Practice (GFP) Sapi Potong berkaitan erat dengan tercapainya swasembada daging yang dicanangkan oleh pemerintah. Oleh karena itu, perlu dilakukan kajian tentang penerapan Good Farming Practice (GFP) Sapi Potong. Tujuan dilakukan kajian ini adalah :

1. Mengidentifikasi penerapan Good Farming Practice (GFP) Sapi Potong di Kecamatan Kasreman, Kabupaten Ngawi.

2. mendeskripsikan hubungan karakteristik peternak (umur, pendidikan, lama beternak, jumlah kepemilikan ternak, intensitas penyuluhan, dan kekosmopolitan) dengan penerapan Good Farming Practice (GFP) Sapi Potong di Kecamatan Kasreman, Kabupaten Ngawi.

\section{METODE PENELITIAN}

Lokasi pelaksanaan penelitian adalah Kecamatan Kasreman Kabupaten Ngawi. Jenis penelitian adalah penelitian kuantitatif 
dengan metode survei dan analisis data yang digunakan dalam penelitian ini adalah analisis statistik inferensial.

Populasi dalam penelitian ini adalah seluruh peternak yang terdaftar sebagai anggota dalam seluruh Kelompok Tani di Kecamatan Kasreman Kabupaten Ngawi. Sampel dalam penelitian ini sebanyak 32 sampel yang terbagi merata dalam 8 desa di Kecamatan Kasreman. Teknik pengambilan sampel pada penelitian ini adalah Area Probability Sample. Teknik ini dilakukan dengan mengambil wakil dari seluruh 8 desa yang terdapat di Kecamatan Kasreman Kabupaten Ngawi.

Tabel 1. Pengambilan Sampel

\begin{tabular}{clcc}
\hline NO & \multicolumn{1}{c}{ Desa } & Perhitungan Sampel & Jumlah Sampel \\
\hline 1 & Jatirejo & $32 / 8$ & 4 \\
2 & Cangakan & $32 / 8$ & 4 \\
3 & Karangmalang & $32 / 8$ & 4 \\
4 & Kasreman & $32 / 8$ & 4 \\
5 & Legokulon & $32 / 8$ & 4 \\
6 & Tawun & $32 / 8$ & 4 \\
7 & Kiyonten & $32 / 8$ & 4 \\
8 & Gunungsari & $32 / 8$ & 4 \\
\hline & & & $\mathbf{3 2}$ \\
\hline
\end{tabular}

Sumber: Analisis Data Sekunder, 2017 adalah:

Adapun variabel dalam penelitian ini

1. Variabel Independen. Variabel independen pada penelitian ini terdiri dari karakteristik internal (umur, pendidikan, lama usaha, dan jumlah kepemilikan ternak) dan karakteristik eksternal (intensitas penyuluhan dan kekosmopolitan).

2. Variabel Dependen. Variabel dependen penelitian ini adalah penerapan Good Farming Practice (GFP) Sapi Potong.

1. $\operatorname{Umur}\left(\mathrm{X}_{1}\right)$

2. Pendidikan $\left(\mathrm{X}_{2}\right)$

3. Lama beternak $\left(\mathrm{X}_{3}\right)$

4. Jumlah kepemilikan ternak $\left(X_{4}\right)$

Variabel Independen

(Karakteristik Eksternal)

1. Intensitas penyuluhan $\left(\mathrm{X}_{5}\right)$

2. Kekosmopolitan $\left(\mathrm{X}_{6}\right)$

Gambar 1. Hubungan Variabel Independen dengan Dependen

Data yang digunakan sebagai bahan penelitian ini diperoleh dari:

1. Data Primer. Data primer pada penelitian ini diperoleh dari hasil melakukan survei dengan menggunakan kuesioner.

2. Data Sekunder. Data sekunder pada penelitian ini diperoleh dari Programa Penyuluhan Kecamatan Kasreman 59 | Jurnal Agriekstensia Vol. 17 No. 1 Juli 2018
Kabupaten Ngawi Tahun 2016, Kabupaten Ngawi Dalam Angka Tahun 2015, Kecamatan Kasreman Dalam Angka Tahun 2016, dan naskah-naskah lain yang terkait dengan penelitian ini.

\section{HASIL DAN PEMBAHASAN}


Kecamatan Kasreman sebelah Utara berbatasan langsung dengan Kabupaten Bojonegoro. Luas wilayah Kecamatan Kasreman adalah 3149,24 ha, terbagi dalam $51,49 \%$ lahan sawah dan 58,59 \% lahan bukan sawah atau sekitar 1842,54 ha sesuai dengan Peraturan Daerah Kabupaten Ngawi tahun 2006., secara administrasi wilayah ini terbagi ke dalam 8 desa.

Wilayah Kecamatan Kasreman terbagi dalam 8 Desa sebagaimana tercantum dalam $\quad$ Tabel 2.

Tabel 2. Desa di Kecamatan Kasreman

\begin{tabular}{clcc}
\hline No & \multicolumn{1}{c}{ Nama Desa } & Topografi & Ketinggian $(\mathbf{m})$ \\
\hline 1 & Jatirejo & Datar & 689 \\
2 & Cangakan & Datar & 531 \\
3 & Karangmalang & Datar & 438 \\
4 & Kasreman & Datar \& Bukit & 418 \\
5 & Legokulon & Datar \& Bukit & 301 \\
6 & Tawun & Datar \& Bukit & 342 \\
7 & Kiyonten & Bukit & 423 \\
8 & Gunungsari & Bukit & 402
\end{tabular}

Sumber: Kecamatan Kasreman dalam Angka, 2016

Topografi Kecamatan Kasreman secara umum merupakan tanah datar dengan diselingi perbukitan. Wilayah Kecamatan Kasreman terletak pada ketinggian antara 301 meter s.d. 689 meter.
Populasi ternak sapi merupakan populasi ternak tertinggi yaitu sebanyak 4.245 ekor, populasi ternak kambing pada peringkat kedua yaitu sebanyak 3.334 ekor, sedangkan pada peringkat ketiga yaitu domba sebanyak 647 ekor.

Tabel 3. Populasi Ternak Besar dan Ternak Kecil (dalam ekor)

\begin{tabular}{clcccccc}
\hline No & Desa/Kelurahan & $\begin{array}{c}\text { Sapi } \\
\text { Potong }\end{array}$ & Kerbau & Kuda & Kambing & Domba & Kelinci \\
\hline 1 & Jatirejo & 485 & - & - & 434 & 141 & 39 \\
2 & Cangakan & 130 & - & 2 & 299 & 52 & 23 \\
3 & Karangmalang & 268 & - & 1 & 204 & 17 & 13 \\
4 & Kasreman & 553 & - & 1 & 261 & 37 & 32 \\
5 & Legokulon & 569 & - & - & 942 & 180 & 45 \\
6 & Tawun & 623 & - & - & 358 & 64 & 41 \\
7 & Kiyonten & 631 & - & - & 409 & 58 & 64 \\
8 & Gunungsari & 986 & 6 & - & 427 & 98 & 17 \\
\hline & Jumlah & $\mathbf{4 . 2 4 5}$ & $\mathbf{6}$ & $\mathbf{4}$ & $\mathbf{3 . 3 3 4}$ & $\mathbf{6 4 7}$ & $\mathbf{2 7 4}$ \\
\hline
\end{tabular}

Sumber: Programa Penyuluhan Kecamatan Kasreman, 2016

Jumlah populasi ternak sapi di Kecamatan Kasreman sebanyak 4.245 ekor tersebut hanya sebesar $7,54 \%$ dari total populasi ternak sapi di Kabupaten Ngawi. Melihat kontribusi yang rendah tersebut, populasi ternak sapi potong di Kecamatan Kasreman dapat ditingkatkan. Hal ini sejalan dengan Peraturan Menteri Pertanian Republik Indonesia Nomor
46/Permentan/PK.210/8/2015 tentang Budi Daya Sapi Potong yang Baik yang bertujuan untuk meningkatkan populasi, produksi dan produktivitas ternak sapi.

Jumlah penduduk di Kecamatan Kasreman adalah 25.227 jiwa, terdiri dari 12.651 jiwa laki-laki dan 12.576 jiwa perempuan sebagaimana dapat dilihat pada Tabel 4. 
Tabel 4. Jumlah Penduduk Menurut Jenis Kelamin

\begin{tabular}{clccc}
\hline No & \multicolumn{1}{c}{ Desa } & Laki-laki & Perempuan & Jumlah \\
\hline 1 & Jatirejo & 1.804 & 1.827 & 3.631 \\
2 & Cangakan & 1.293 & 1.291 & 2.584 \\
3 & Karangmalang & 1.127 & 1.137 & 2.264 \\
4 & Kasreman & 1.475 & 1.473 & 2.948 \\
5 & Legokulon & 1.394 & 1.445 & 2.839 \\
6 & Tawun & 2.387 & 2.164 & 4.551 \\
7 & Kiyonten & 1.251 & 1.324 & 2.575 \\
8 & Gunungsari & 1.920 & 1.915 & 3.835 \\
\hline \multicolumn{2}{r}{ Total } & 12.651 & 12.576 & 25.227 \\
\hline
\end{tabular}

Sumber: Kecamatan Kasreman dalam Angka, 2016

Sebagian besar penduduk $(67,92 \%)$ di Kecamatan Kasreman menamatkan pendidikan setara SD. Hal ini menunjukkan bahwa tingkat pendidikan penduduk
Kecamatan Kasreman rendah. Sebaran tingkat pendidikan penduduk Kecamatan Kasreman selengkapnya disajikan pada Tabel 5.

Tabel 5. Jumlah Penduduk Menurut Pendidikan

\begin{tabular}{|c|c|c|c|c|c|c|}
\hline No & Desa & $\geq$ Tamat SD & $\begin{array}{l}\text { Tamat } \\
\text { SMP }\end{array}$ & $\begin{array}{l}\text { Tamat } \\
\text { SMA }\end{array}$ & Tamat PT & Jumlah \\
\hline 1 & Jatirejo & 2.462 & 659 & 474 & 36 & 3.631 \\
\hline 2 & Cangakan & 1.971 & 258 & 264 & 91 & 2.584 \\
\hline 3 & Karangmalang & 1.566 & 416 & 262 & 20 & 2.264 \\
\hline 4 & Kasreman & 2.106 & 423 & 395 & 24 & 2.948 \\
\hline 5 & Legokulon & 1.909 & 496 & 404 & 30 & 2.839 \\
\hline 6 & Tawun & 2.782 & 966 & 764 & 39 & 4.551 \\
\hline 7 & Kiyonten & 1.545 & 609 & 403 & 18 & 2.575 \\
\hline 8 & Gunungsari & 2.794 & 798 & 232 & 11 & 3.835 \\
\hline & Total & $\mathbf{1 7 . 1 3 5}$ & 4.625 & 3.198 & 269 & 25.227 \\
\hline & $\%$ & 67,92 & 18,33 & 12,68 & 1,07 & 100,00 \\
\hline
\end{tabular}

Sumber: Kecamatan Kasreman dalam Angka, 2016

Sebagian besar penduduk di Kecamatan Kasreman tergolong pada kategori usia produktif (15-64 tahun) sesuai definisi dari Badan Pusat Statistik dengan rincian dapat dilihat Tabel 6.

Tabel 6 menunjukkan bahwa rentang usia penduduk di Kecamatan Kasreman tertinggi adalah pada usia 15-19 tahun yang mencapai 2.358 orang atau setara 9,35\% dari populasi penduduk Kecamatan Kasreman. Tabel 6 juga menunjukkan bahwa penduduk yang termasuk kategori usia produktif (1564 tahun) sejumlah 16.997 (67,38\%). Hal tersebut juga menunjukkan tingginya angkatan kerja di Kecamatan Kasreman.
Umur adalah usia responden pada saat pelaksanaan penelitian di lapangan. Umur merupakan salah satu indikator yang menunjukkan kemampuan fisik seseorang. Orang yang memiliki umur yang lebih tua fisiknya lebih lemah dibandingkan dengan orang yang berumur lebih muda. Umur seorang peternak memiliki hubungan dengan produktifitas kerja mereka dalam kegiatan usaha peternakan. Umur berkaitan erat dengan pola pikir peternak dalam menentukan sistem manajemen yang akan diterapkan dalam usaha peternakan (Karmila, 2013:31). 
Tabel 6. Jumlah Penduduk Menurut Usia

\begin{tabular}{rcrrrr}
\hline No & Umur & Laki-laki & Perempuan & \multicolumn{1}{c}{ Jumlah } & \multicolumn{1}{c}{$\%$} \\
\hline 1 & $0-4$ & 992 & 909 & 1.901 & 7.54 \\
2 & $5-9$ & 1.068 & 955 & 2.023 & 8.02 \\
3 & $10-14$ & 1.199 & 1.112 & 2.311 & 9.16 \\
4 & $15-19$ & 1.262 & 1.096 & 2.358 & 9.35 \\
5 & $20-24$ & 884 & 878 & 1.762 & 6.98 \\
6 & $25-29$ & 925 & 974 & 1.899 & 7.53 \\
7 & $30-34$ & 949 & 1.040 & 1.989 & 7.88 \\
8 & $35-39$ & 1.030 & 1.075 & 2.105 & 8.34 \\
9 & $40-44$ & 968 & 936 & 1.904 & 7.55 \\
10 & $45-49$ & 856 & 759 & 1.615 & 6.40 \\
11 & $50-54$ & 643 & 623 & 1.266 & 5.02 \\
12 & $55-59$ & 514 & 534 & 1.048 & 4.15 \\
13 & $60-64$ & 483 & 568 & 1.051 & 4.17 \\
14 & $65-69$ & 347 & 449 & 796 & 3.16 \\
15 & $70-74$ & 300 & 355 & 655 & 2.60 \\
16 & 75 & 231 & 313 & 544 & 2.16 \\
\hline
\end{tabular}

Sebaran umur responden pada penelitian ini disajikan pada Tabel 7.

Tabel 7. Umur Responden

\begin{tabular}{clrr}
\hline No & \multicolumn{1}{c}{ Umur } & Jml & \multicolumn{1}{c}{$\%$} \\
\hline 1 & 0-14 (Non-produktif) & 0 & 0 \\
2 & 19-64 (Produktif) & 31 & 96,87 \\
3 & $\begin{array}{l}\text { 64 ke atas (Non- } \\
\text { produktif) }\end{array}$ & 1 & 3,13 \\
\hline \multicolumn{1}{c}{ Total } & $\mathbf{3 2}$ & $\mathbf{1 0 0 , 0 0}$
\end{tabular}

Sumber: Data Primer Diolah, 2017

Tabel 7 menunjukkan bahwa responden yang dikategorikan sebagai usia produktif sebanyak 31 responden $(96,87 \%)$, dan bukan usia produktif sebanyak 1 responden $(3,13 \%)$. Keuntungan yang diperoleh dari usia produktif adalah responden mampu melakukan pekerjaan dan menghasilkan sesuatu bila dibandingkan dengan usia non-produktif.

Pendidikan adalah pendidikan formal yang ditempuh oleh responden pada saat pelaksanaan penelitian. Pendidikan responden merupakan indikator yang mencerminkan kemampuan responden untuk menyelesaikan pekerjaan atau tanggung jawab. Pendidikan sangat dibutuhkan untuk menjalankan suatu tidak terkecuali usaha peternakan. Sebaran tingkat pendidikan responden penelitian ini disajikan pada Tabel 8.

Tabel 8. Tingkat Pendidikan Responden

\begin{tabular}{clrr}
\hline No & $\begin{array}{c}\text { Tingkat } \\
\text { Pendidikan }\end{array}$ & Jumlah & \% \\
\hline 1 & $>$ SD & 14 & 43.75 \\
2 & SLTP & 8 & 25.00 \\
3 & SLTA & 6 & 18.75 \\
4 & Perguruan & & \\
& Tinggi & 4 & 12.50 \\
\hline & Total & $\mathbf{3 2}$ & $\mathbf{1 0 0 . 0 0}$ \\
\hline Sumber: Data Primer Diolah, 2017 & &
\end{tabular}

Tabel 8 menunjukkan bahwa tingkat pendidikan responden tergolong rendah. Sebanyak 14 responden $(43,75 \%)$ berpendidikan setingkat SD, 8 responden $(25,00 \%)$ berpendidikan SLTP, sedangkan responden dengan pendidikan SMA sebanyak 6 orang $(18,75 \%)$. Responden yang menyelesiakan pendidikan formal di 
Perguruan Tinggi sebanyak 4 orang $(12,50 \%)$.

Tinggi rendahnya pendidikan yang dimiliki oleh responden berpengaruh terhadap tingkap kemampuan dan cara berpikir responden miliki, hal ini sesuai dengan pendapat Lestraningsih dan Basuki (2008) dalam Utami (2015:29) yang menyatakan bahwa tingkat pendidikan berpengaruh terhadap kemampuan peternak dalam penerapan teknologi.

Lama usaha merupakan lama waktu yang dilalui oleh responden dalam menjalankan usaha peternakan sapi potong pada saat dilaksanakan penelitian. Pengalaman beternak diperoleh responden dari lama responden menjalankan usaha peternakan sapi potong.

Tabel 2. Lama Usaha Responden

\begin{tabular}{clrr}
\hline No & Lama Usaha & Jml & \multicolumn{1}{c}{$\%$} \\
\hline 1 & $\leq 10$ tahun & 13 & 40.63 \\
2 & $10-20$ tahun & 16 & 50.00 \\
3 & 21 tahun ke atas & 3 & 9.38 \\
\hline & Total & $\mathbf{3 2}$ & $\mathbf{1 0 0}$ \\
\hline
\end{tabular}

Sumber: Data Primer Diolah, 2017

Tabel 9 menunjukkan bahwa responden pada penelitian ini memiliki pengalaman usaha beternak sapi potong pada rentang 10-20 tahun (16 orang dengan persentase 50,00\%). Sebanyak 13 responden $(40,63 \%)$ memiliki lama usaha pada rentang 0-10 tahun dan 3 responden $(9,38 \%)$ memiliki pengalaman usaha di atas 21 tahun. Semakin lama responden menjalankan usaha peternakan diharapkan semakin banyak pengetahuan dan keterampilan yang diperolah dalam menjalankan usaha peternakan. Lama beternak merupakan faktor penting yang harus dimiliki peternak untuk memutuskan segala kebijakan yang akan diterapkan dalam usahanya (Utami, 2015:30).

Jumlah kepemilikan ternak merupakan ternak sapi potong yang dimiliki oleh responden pada pelaksanaan penelitian yang dinyatakan dalam ST (Satuan Unit). Jumlah kepemilikan ternak tiap-tiap 63 | Jurnal Agriekstensia Vol. 17 No. 1 Juli 2018 responden berbeda, tergantung dari skala usaha yang dijalankan oleh responden. Sebaran lama usaha responden penelitian ini disajikan pada Tabel 10.

Tabel 10. Jumlah Kepemilikan Ternak Responden

\begin{tabular}{clrr}
\hline No & $\begin{array}{c}\text { Jumlah } \\
\text { Ternak (ST) }\end{array}$ & Jumlah & \% \\
\hline 1 & $\leq 2$ ST & 22 & 68,75 \\
2 & $2,1-4$ ST & 6 & 18,75 \\
3 & 4 ST ke atas & 4 & 12,50 \\
\hline & Total & $\mathbf{3 2}$ & $\mathbf{1 0 0}$ \\
\hline
\end{tabular}

Sumber: Data Primer Diolah, 2017

Tabel 10 menunjukkan bahwa sebagian besar responden memiliki ternak dalam jumlah yang sedikit. Responden dengan kepemilikan ternak sapi maksimal 2 ST sebanyak 22 responden dengan persentase 68,75\%. Responden dengan kepemilikan ternak sapi di atas 2 ST sampai dengan 4 ST sebanyak 6 responden dengan persentase $18,75 \%$ dan 4 responden $(12,50 \%)$ dengan kepemilikan ternak sapi di atas $4 \mathrm{ST}$.

Hal tersebut di atas sesuai dengan ciri-ciri peternakan rakyat: 1). Skala usaha relatif kecil, 2). Merupakan usaha rumah tangga, 3). Dilakukan sebagai usaha sampingan, 4). Menggunakan teknologi sederhana (Eni dalam Matondang dan Rusdiana, 2013:132).

Intensitas penyuluhan merupakan frekuensi responden dalam mengikuti penyuluhan yang terkait dengan usaha sapi potong. Peran intensitas penyuluhan terhadap keberhasilan adopsi teknologi di suatu wilayah sangat diperhitungkan (Nur Mustakim, 2015:50). Sebaran intensitas penyuluhan responden penelitian ini disajikan pada Tabel 11.

Tabel 11. Intensitas Penyuluhan Responden

\begin{tabular}{|c|c|c|c|}
\hline No & $\begin{array}{c}\text { Intensitas } \\
\text { Penyuluhan }\end{array}$ & Jml & $\%$ \\
\hline 1 & $\begin{array}{l}\text { Rendah }(\leq 1 \mathrm{x} \\
\text { /bulan })\end{array}$ & 26 & 81,25 \\
\hline 2 & Sedang (2x /bulan) & 2 & 6,25 \\
\hline
\end{tabular}




\begin{tabular}{crrr}
\hline 3 & $\begin{array}{l}\text { Tinggi } \\
\text { bulan) }\end{array}$ & $42 \mathrm{x} /$ & 12,50 \\
\hline Total & $\mathbf{3 2}$ & $\mathbf{1 0 0 , 0 0}$ \\
\hline
\end{tabular}

Sumber: Data Primer Diolah, 2017

Tabel 11 menunjukkan bahwa sebanyak 26 responden $(81,25 \%)$ pada penelitian ini dikategorikan sangat jarang mengikuti penyuluhan (mengikuti penyuluhan $0-1 \mathrm{x}$ per bulan). Sedangkan 2 responden $(6,25 \%)$ mengikuti penyuluhan antara 1-2x dalam sebulan, dan di atas $2 x$ dalam sebulan sebanyak 4 orang. Kesimpulan yang dapat ditarik dari data yang tersaji pada Tabel 11 adalah intensitas penyuluhan responden penelitian ini rendah.

Kekosmopolitan merupakan tingkat keterbukaan responden terhadap informasi terkait usaha peternakan sapi potong. Sebaran kekosmopolitan responden penelitian ini disajikan pada Tabel 12 .

Tabel 12. Kekosmopolitan Responden

\begin{tabular}{clrr}
\hline No & $\begin{array}{l}\text { Kekosmopolitan } \\
\text { Responden }\end{array}$ & Jml & \% \\
\hline 1 & Rendah $(\leq 1 \mathrm{x}$ & 24 & 75,00 \\
& /bulan) & 3 & 9,38 \\
2 & Sedang $(2 \mathrm{x} /$ bulan $)$ & & \\
& Tinggi $(>2 \mathrm{x} /$ & 5 & 15,62 \\
\hline & bulan) & $\mathbf{3 2}$ & $\mathbf{1 0 0 , 0 0}$ \\
\hline
\end{tabular}

Sumber: Data Primer Diolah, 2017
Tabel 12 menunjukkan bahwa responden penelitian dengan tingkat kekosmopolitan rendah sebanyak 24 responden $(75,00 \%)$. Sedangkan responden dengan tingkat kekosmopolitan sedang sebanyak 3 responden $(9,38 \%)$ dan responden dengan tingkat kekosmopolitan tinggi sebanyak 5 responden $(15,63 \%)$. Sebaran data tersebut memberikan kesimpulan bahwa kekosmopolitan responden rendah. Sedangkan semakin tinggi kekosmopolitan responden maka akan semakin tinggi tingkat penerapan teknologinya (Khasanah, 2008:133).

Hasil survei penerapan Good Farming Practice (GFP) Sapi Potong di Kecamatan Kasreman Kabupaten Ngawi sebagaimana yang tercantum dalam Tabel 13.

Tabel 13 menunjukkan bahwa kategori penerapan Good Farming Practice (GFP) Sapi Potong di Kecamatan Kasreman termasuk kategori sedang. Ruang lingkung Prasarana \& Sarana merupakan ruang lingkup dengan persentase penerapan terendah $(33,63 \%)$. Sedangkan ruang lingkup Pengawasan, Pembinaan dan Pelaporan merupakan ruang lingkup tertinggi dengan persentase $52,50 \%$.

Tabel 13. Hasil Survei Penerapan GFP Sapi Potong

\begin{tabular}{llrrrl}
\hline No & \multicolumn{1}{c}{ Ruang Lingkup } & Skor Rata2 & Skor Max & $(\boldsymbol{\%})$ & Kategori \\
\hline 1 & Prasarana \& Sarana & 16,81 & 55 & 33,63 & Sedang \\
2 & Pola Pemeliharaan & 6,69 & 15 & 44,58 & Sedang \\
3 & Kesejahteraan \& Kesehatan Hewan & 4,56 & 10 & 45,63 & Sedang \\
4 & Pelestarian Lingkungan Hidup & 2,56 & 5 & 51,25 & Sedang \\
5 & SDM & 4,75 & 10 & 47,50 & Sedang \\
6 & Pengawasan, Pembinaan dan & 2,63 & 5 & 52,50 & Sedang \\
\hline
\end{tabular}

Sumber: Data Primer Diolah, 2017

Untuk mengetahui hubungan antara karakteristik peternak dengan penerapan Good Farming Practice (GFP) Sapi Potong dilakukan uji hipotesis asosiatif berupa analisis korelasi dengan menggunakan bantuan software IBM SPSS Statistics 20 for Windows. Variabel terbagi menjadi 6 : Umur (X1), Pendidikan (X2), Lama Beternak (X3), 
Jumlah Kepemilikan Ternak (X4), Intensitas Penyuluhan (X5), Kekosmopolitan (X6) dan Penerapan (Y).

Hasil perhitungan analisis korelasi Karakteristik Peternak dengan Penerapan
Good Farming Practice (GFP) Sapi Potong di Kecamatan Kasreman Kabupaten Ngawi Provinsi Jawa Timur dapat dilihat pada Tabel 14.

Tabel 14. Hubungan Karakteristik dengan Penerapan GFP Sapi Potong

\begin{tabular}{llcc}
\hline \multirow{2}{*}{ No } & \multicolumn{1}{c}{ Variabel Independen } & \multicolumn{2}{c}{$\begin{array}{c}\text { Variabel Dependen } \\
\text { (Penerapan GFP) }\end{array}$} \\
\cline { 3 - 4 } & & -0.374 & Sig \\
\hline 1 & Umur (X1) & 0.440 & .035 \\
2 & Pendidikan (X2) & -0.332 & .012 \\
3 & Lama Beternak (X3) & 0.376 & .063 \\
4 & Jumlah Kepemilikan Ternak (X4) & 0.786 & .034 \\
5 & Intensitas Penyuluhan (X5) & 0.353 & .000 \\
6 & Kekosmopolitan (X6) & .047 \\
\hline
\end{tabular}

Sumber: Data Primer Diolah, 2017

\section{Hubungan Umur dengan Penerapan Good Farming Practice (GFP) Sapi Potong}

Tabel 14 menunjukkan bahwa nilai signifikansi antara Variabel Umur (X1) dengan Variabel Penerapan GFP adalah 0.035 . Karena nilai sig. $<0.05$, maka umur dinyatakan memiliki korelasi yang signifikan terhadap penerapan Good Farming Practice (GFP) Sapi Potong. Sedangkan nilai r -0.374 mengindikasikan korelasi yang rendah dengan arah hubungan negatif.

Hal ini sejalan dengan dengan pendapat Saidah (2008:34) yang menyatakan bahwa peternak dengan usia lanjut umumnya kurang berminat dalam mengkomunikasikan berbagai hal yang berkaitan dengan usaha peternakannya. Hal ini diperkuat dengan pendapat Soekartawi dalam Saidah (2008:35) yang menyebutkan bahwa makin muda usia peternak biasanya mempunyai semangat ingin tahu mengenai hal-hal yang belum diketahui dan peternak yang relatif lebih tua umumnya kurang menerima perubahan dibandingkan dengan yang berusia lebih muda.

Arah hubungan negatif antara umur dengan penerapan penerapan Good Farming Practice (GFP) Sapi Potong dikarenakan responden penelitian memiliki rata-rata umur 50,47 tahun (Lampiran 13). Moekijad dalam Pandapotan (2013) menyebutkan bahwa umur di atas 50 tahun tenaga kerja cenderung statis, keadaannya kurang mampu dan sifatnya kurang giat untuk hal-hal baru. Oleh karena itu, semakin tinggi umur peternak akan semakin menurun penerapan Good Farming Practice (GFP) Sapi Potong.

Hubungan Pendidikan dengan Penerapan Good Farming Practice (GFP) Sapi Potong

Tabel 14 menunjukkan bahwa nilai signifikansi antara Variabel Pendidikan (X2) dengan Variabel Penerapan GFP adalah 0.012. Karena nilai sig. $<0.05$, maka pendidikan dinyatakan memiliki korelasi yang signifikan terhadap penerapan Good Farming Practice (GFP) Sapi Potong. Sedangkan nilai r 0.440 mengindikasikan korelasi yang sedang dengan arah hubungan positif.

Kesimpulan dari hasil analisis hubungan pendidikan dengan penerapan Good Farming Practice (GFP) Sapi Potong adalah bahwa semakin tinggi pendidikan peternak maka akan semakin tinggi penerapan Good Farming Practice (GFP) Sapi Potong. Hal ini sesuai dengan pendapat Wardhani dalam Saidah (2008:35) yang menyebutkan bahwa seseorang yang memiliki tingkat pendidikan yang lebih tinggi umumnya lebih menyadari akan 
kebutuhan informasi sehingga lebih banyak sumber informasi.

\section{Hubungan Lama Beternak dengan Penerapan Good Farming Practice (GFP) Sapi Potong}

Tabel 14 menunjukkan bahwa nilai signifikansi antara Variabel Lama Beternak (X3) dengan Variabel Penerapan GFP adalah 0.063 . Karena nilai sig. $>0.05$, maka lama beternak dinyatakan tidak memiliki korelasi yang signifikan terhadap penerapan Good Farming Practice (GFP) Sapi Potong. Sedangkan nilai $\mathrm{r}-0.332$ mengindikasikan korelasi yang rendah dengan arah hubungan positif.

Kesimpulan dari hasil analisis hubungan lama beternak dengan penerapan Good Farming Practice (GFP) Sapi Potong adalah tidak ada hubungan lama beternak dengan penerapan Good Farming Practice (GFP) Sapi Potong. Hal ini didasari pada keadaan peternak di Kecamatan Kasreman yang menjadikan usaha peternakan sapi potong sebagai usaha sampingan yang merupakan salah satu ciri usaha peternakan rakyat. Kesimpulan ini sejalan dengan pendapat Saidah (2008:38) yang menyebutkan bahwa hubungan pengalaman peternak dengan efektivitas komunikasi interpersonal adalah negatif.

\section{Hubungan Jumlah Kepemilikan Ternak dengan Penerapan Good Farming Practice (GFP) Sapi Potong}

Tabel 14 menunjukkan bahwa nilai signifikansi antara Variabel Jumlah Kepemilikan Ternak (X4) dengan Variabel Penerapan GFP adalah 0.034. Karena nilai sig. $<0.05$, maka jumlah kepemilikan ternak dinyatakan memiliki korelasi yang signifikan terhadap penerapan Good Farming Practice (GFP) Sapi Potong. Sedangkan nilai r 0.376 mengindikasikan korelasi yang rendah dengan arah hubungan positif.

Diartikan bahwa semakin tinggi jumlah kepemilikan ternak akan semakin tinggi penerapan Good Farming Practice $(G F P)$ Sapi Potong, karena semakin banyak jumlah ternak yang dimiliki peternak 66 | Jurnal Agriekstensia Vol. 17 No. 1 Juli 2018 semakin menyadari keuntungan yang dari peternakan sapi potong. Oleh karena itu, peternak semakin berusaha menjalankan usaha peternakan dengan lebih baik dengan menerapkan Good Farming Practice (GFP) Sapi Potong. Hal tersebut sejalan dengan hasil penelitian Kristianto (2009:114) yang menyebutkan bahwa hubungan kepemilikan ternak dengan keberhasilan peternak merupakan hubungan yang signifikan dan bersifat positif.

Hubungan Intensitas Penyuluhan dengan Penerapan Good Farming Practice (GFP) Sapi Potong

Tabel 14 menunjukkan bahwa nilai signifikansi antara Variabel Intensitas Penyuluhan (X5) dengan Variabel Penerapan GFP adalah 0.000. Karena nilai sig. < 0.05, maka intensitas penyuluhan dinyatakan memiliki korelasi yang signifikan terhadap penerapan Good Farming Practice (GFP) Sapi Potong. Sedangkan nilai r 0.786 mengindikasikan korelasi yang tinggi dengan arah hubungan positif.

Kesimpulan dari hasil analisis hubungan intensitas penyuluhan dengan penerapan Good Farming Practice (GFP) Sapi Potong adalah semakin banyak peternak mengikuti penyuluhan maka semakin tinggi penerapan Good Farming Practice (GFP) Sapi Potong. Tingginya keikutsertaan peternak dalam penyuluhan menunjukkan bahwa peternak menyadari informasi yang disampaikan dalam penyuluhan bermanfaat untuk memperbaiki usaha peternakan yang dijalankan. Hal tersebut di atas dikuatkan dengan pendapat Mustakim (2015:61) yang menyebutkan bahwa variabel intensitas penyuluhan berpengaruh positif dan signifikan terhadap persepsi peternak pada teknologi.

\section{Hubungan Kekosmopolitan dengan Penerapan Good Farming Practice (GFP) Sapi Potong}

Tabel 14 menunjukkan bahwa nilai signifikansi antara Variabel Kekosmopolitan (X6) dengan Variabel Penerapan GFP adalah 0.047. Karena nilai sig. $<0.05$, maka 
kekosmopolitan dinyatakan memiliki korelasi yang signifikan terhadap penerapan Good Farming Practice (GFP) Sapi Potong. Sedangkan nilai r 0.353 mengindikasikan korelasi yang rendah dengan arah hubungan positif.

Kesimpulan dari hasil analisis hubungan kekosmopolitan dengan penerapan Good Farming Practice (GFP) Sapi Potong adalah semakin tinggi kekosmopolitan maka semakin tinggi penerapan Good Farming Practice (GFP) Sapi Potong. Semakin sering peternak berkunjung ke daerah lain menunjukkan peternak semakin membutuhkan informasi untuk meningkatkan usaha peternakan yang dijalankan. Hal tersebut di atas sejalan dengan pendapat Bulkis (2015:37) yang menyatakan bahwa kekosmopolitan berkaitan erat dengan perilaku komunikasi. Semakin terbuka seorang peternak terhadap dunia luar dan bersedia menerima ide baru dalam pengembangan usaha peternakan maka akan semakin tinggi pengetahuan yang dimiliki. Sehingga, semakin tinggi tingkat kekosmopolitan peternak akan semakin tinggi penerapan Good Farming Practice (GFP) Sapi Potong.

\section{KESIMPULAN DAN SARAN}

\section{Kesimpulan}

Berdasarkan hasil penelitian yang telah dilakukan, dapat disimpulkan sebagai berikut:

1. Penerapan Good Farming Practice (GFP) Sapi Potong di Kecamatan Kasreman Kabupaten Ngawi terbagi dalam 6 ruang lingkup. Penerapan pada ruang lingkup Prasarana \& Sarana sebesar $33,63 \%$, penerapan pada ruang lingkup Pola Pemeliharaan sebesar 44,58\%, penerapan pada ruang lingkup Kesejahteraan \& Kesehatan Hewan sebesar $45,63 \%$, penerapan pada ruang lingkup Pelestarian Lingkungan Hidup sebesar $51,25 \%$, penerapan pada ruang lingkup SDM sebesar 47,50\%, dan penerapan pada ruang lingkup Pengawasan, Pembinaan dan Pelaporan sebesar 52,50\%. Penerapan Good Garming Practice (GFP) Sapi Potong di Kecamatan Kasreman Kabupaten Ngawi disimpulkan termasuk pada kategori sedang.

2. Hubungan karakteristik peternak dengan penerapan Good Farming Practice (GFP) Sapi Potong di Kecamatan Kasreman Kabupaten Ngawi adalah:

a. Umur memiliki hubungan yang signifikan dengan penerapan Good Farming Practice (GFP) Sapi Potong dengan $\mathrm{r}-0.374$ dan sig. 0.035

b. Pendidikan memiliki hubungan yang signifikan dengan penerapan Good Farming Practice (GFP) Sapi Potong dengan $\mathrm{r} 0.440$ dan sig. 0.012

c. Lama beternak tidak berhubungan signifikan dengan penerapan Good Farming Practice (GFP) Sapi Potong dengan $\mathrm{r}-0.332$ dan sig. 0.063

d. Jumlah kepemilikan ternak memiliki hubungan yang signifikan dengan penerapan Good Farming Practice (GFP) Sapi Potong dengan r 0.376 dan sig. 0.034

e. Intensitas penyuluhan memiliki hubungan yang signifikan dengan penerapan Good Farming Practice (GFP) Sapi Potong dengan r 0.786 dan sig. 0.000

f. Kekosmopolitan memiliki hubungan yang signifikan dengan penerapan Good Farming Practice (GFP) Sapi Potong dengan $\mathrm{r} 0.353$ dan sig. 0.047 .

\section{Saran}

Saran yang dapat diberikan penulis adalah sebagai berikut:

1. Diperlukan peningkatan penerapan Good Farming Practice (GFP) Sapi Potong sebagai usaha untuk mendukung program swasembada daging sapi yang digalakkan oleh pemerintah dengan pendampingan peternak oleh penyuluh.

2. Intensitas penyuluhan mengenai penerapan Good Farming Practice (GFP) Sapi Potong perlu ditingkatkan, karena memiliki korelasi yang tinggi dan 
signifikan terhadap penerapan Good Farming Practice (GFP) Sapi Potong

3. Instansi terkait harus mendukung program swasembada daging sapi.

\section{DAFTAR PUSTAKA}

Anonimous. 2006. Undang-undang tentang Sistem Penyuluhan Pertanian, Perikanan dan Kehutanan. Jakarta: Departemen Pertanian.

Anonimous. 2015. Ngawi Dalam Angka 2015. Ngawi.: Badan Pusat Statistik Kabupaten Ngawi.

Anonimous. 2015. Pedoman Budi Daya Sapi Potong Yang Baik. Jakarta: Kementerian Pertanian.

Anonimous. 2016. Kecamatan Kasreman Dalam Angka 2016. Ngawi: Badan Pusat Statistik Kabupaten Ngawi.

Anonimous. 2016. Programa Penyuluhan Pertanian Tahun 2016. Ngawi: Balai Penyuluhan Kecamatan Kasreman.

Arikunto, S. 2013. Prosedur Penelitian. Suatu Pendekatan Praktik. Yogyakarta: Rineka Cipta.

Bulkis, 2015. Analisis Jaringan Komunikasi Petani Tanaman Sayuran (Kasus Petani Sayuran di Desa Egon, Kecamatan Waigette, Kabupaten Sikka, Provinsi Nusa Tenggara Timur). Jakarta: Universitas Terbuka.

Cahyono, 2009. Penerapan Sistem Informasi Manajemen Kepegawaian (SIMPEG) di Bidang Pengadaan dan Pengembangan Pegawai Pada Badan Kepegawaian Daerah Kabupaten Subang. Bandung: Universitas Komputer Indonesia.
Karmila. 2013. Faktor-faktor yang Menentukan Pengambilan Keputusan Peternak dalam Memulai Usaha Peternakan Ayam Ras Petelur di Kecamatan Bissappu Kabupaten Bantaeng. Makassar: Universitas Hasanuddin.

Khasanah, W. 2008. Hubungan Faktorfaktor Sosial Ekonomi Petani dengan Tingkat Adopsi Inovasi Teknologi Budidaya Tanaman Jarak Pagar di Kecamatan Lendah Kabupaten Kulon Progo. Surakarta: Universitas Sebelas Maret.

Kristianto, B. 2009. Hubungan Karakteristik Peternak Mitra dengan Keberhasilan Usaha Penggemukan Sapi Peternak Mitra (Studi Kasus Peternak Mitra Sapi Potong UD. Rahmat Alam, Kecamatan Wanayasa, Kabupaten Banjarnegara). Bogor: Institut Pertanian Bogor.

Mardikanto, T. 2009. Sitem Penyuluhan Pertanian. Surakarta: LPP UNS.

Matondang, R.S. 2013. Langkah-langkah Strategis dalam Mencapai Swasembada Daging Sapi/Kerbau 2014. Jurnal Litbang Pertanian, Volume 32 No 3.

Murtiyeni, D. Priyanto dan D. Yulistiani. 2005. Karakteristik Peternak Domba/Kambing dengan Pemeliharaan Digembala/Angon dan Hubungannya dengan Tingkat Adopsi Inovasi Teknologi. Bogor: Balai Penelitian Ternak.

Mustakim, N. M. 2015. Pengaruh Intensitas Penyuluhan dan Tingkat Pengetahuan terhadap Persepsi Peternak pada Teknologi Biogas di Desa Patalassang Kecamatan Tompobulu Kabupaten Bantaeng. Makassar: Universitas Hasanuddin. 
Puspita, Y. 2013. Hubungan Pengetahuan, Sikap, dan Praktek Gizi pada Ibu Hamil di Desa Cikeas Kecamatan Sukaraja Bogor. Bogor: Institut Pertanian Bogor.

Saidah. 2008. Hubungan Karakteristik Peternak dengan Efektivitas Komunikasi Interpersonal. Bogor: Institut Pertanian Bogor.

Salim, E. 2013. Sukses Bisnis dan Beternak Sapi Potong. Yogyakarta: Lily Publisher.

Sikombong, I. 2014. Pengaruh Karakteristik Peternak Terhadap Adopsi Pemanfaatan Limbah Tanaman Pangan Sebagai Pakan Ternak Sapi Potong di Desa Samangki Kecamatan Simbang Kabupaten Maros. Makassar: Universitas Hasanuddin.

Silalahi, U. 2009. Metode Penelitian Sosial. Bandung: Refika Aditama.

Sugiyono. 2016. Statistika Untuk Penelitian. Bandung: Alfabeta.
Sugiyono. 2015. Metode Penelitian Kombinasi (Mixed Methods). Bandung: Alfabeta.

Sugiyono. 2015. Metode Penelitian Kuantitatif, Kualitatif dan $R \& D$. Bandung: Alfabeta.

Suryani, R. 2015. Outlook Komoditas Pertanian Subsektor Peternakan Daging Sapi. Pusat Data dan Sistem Informasi Pertanian Sekretariat Jenderal Kementerian Pertanian. Jakarta: Kementerian Pertanian

Utami, L 2015. Hubungan Karateristik Peternak dengan Skala Usaha Ternak Kerbau di Desa Sumbang Kecamatan Curio Kabupaten Enrekang. Makassar. Universitas Hasanuddin.

Wawan, A. dan Dewi, M. 2011. Teori \& Pengukuran Pengetahuan, Sikap, dan Perilaku Manusia. Yogyakarta: Nuha Medika.

Van den Ban, A.W. dan Hawkins, H.S. 2003. Penyuluhan Pertanian. Yogyakarta: Kanisius. 